J. Range Manage.

49: 24-30 January 1996

\title{
Seasonal diets of sheep in the steppe region of Tierra del Fuego, Argentina
}

\author{
GABRIELA POSSE, JUAN ANCHORENA, AND MARTA B. COLLANTES
}

\author{
Authors are range ecologists, Centro de Ecofisiología Vegetal (CEVEG-CONICET), Serrano 669, (1414) Buenos Aires. \\ Argentina.
}

\begin{abstract}
Sheep diets were determined seasonally for large flocks grazing year-round in 2 landscape types of the Magellanic steppe of Argentina. A tussock-grass steppe of Festuca gracillima Hooker $\mathbf{f}$. dominates the uplands of the whole area. On acid soils (Quaternary landscape), woody variants of the steppe prevail; on neutral soils (Tertiary landscape), woody plants are almost absent and short grasses and forbs are abundant. Principal taxa consumed throughout the year were: Poa L., Deschampsia P.Beauv., and "sedges \& rushes". Consumption of woody species and of the dominant tussock-grass Festuca gracillima increased notably in winter. Despite the large proportion of species in common, diets differed significantly between landscapes. In the Quaternary landscape, which has a higher botanical diversity, diets were more dissimilar among seasons and had a higher annual diversity index. Because of their different composition of forage types the 2 landscapes differed in their overall grazing value. The Tertiary landscape, with a low floristic diversity but richer in highly preferred species as Poa spp. would be a more risky grazing area in winter, when an ice sheet or a snow cover limits harvesting of the lower layer of short grasses and forbs.
\end{abstract}

Key Words: landscape, Magellanic steppe, sheep botanical diet, shrubs, tussock-grass

The relation between grazing animals and their food supply has theoretical and applied importance in range ecology. The domestic sheep (Ovis aries) is classified as an intermediate feeder, a diverse group within the ruminants characterized by dietary plasticity, although its diet often approximates that of the bulk grazers (Huston and Pinchak 1991, Hofmann 1989). Sheep eat coarser food than expected for their corporal size, but they seem to maintain a high diet quality by switching among different types of forage (Schwartz and Ellis 1981).

In the steppe region of northern Tierra del Fuego, Argentina, sheep grazing is extensive (mean stocking rate $=1$ animal $/ \mathrm{ha}$ ),

\footnotetext{
The authors wish to thank Alicia Pelliza Sbriller for training and help with the microhistological methods, Enrique Livraghi for helping with the field work and to "Maria Behety" and "Flamencos" stations' owners and agents. We also thank Susana Stofella for helping us with the English version, Marín Oesterheld for critical comments, and Daniel Soncín for his editing assistance. This research was supported by the Consejo Nacional de Investigaciones Científicas y Técnicas (CONICET PID N 308550088 ).

Manuscript accepted 6 May 1995.
}

with large flocks roaming yearlong in paddocks of 2,000 to more than 4,000 ha. Grazing management is empirical and several problems such as low reproduction rates and high winter mortality of lambs were ascribed to nutritional causes. Nutritional problems could result from historical overgrazing, a situation that was established in several places of the area (Baetti et al. unpublished). As in other regions of unimproved natural pastures, knowledge of plant preferences in relation to resource availability is especially needed to develop sustainable management systems. This is the first study of the foraging behavior of sheep in this area.

Our interest was to study sheep dietary habits in 2 different types of landscape of regional relevance. These landscapes have similar community types but with particular floristic variants, named acidophilous and neuthrophilous, in response to soil characteristics given by different underlying rocks. Collantes et al. (1989) described a soil-nutrient gradient of the steppes and heathlands, associated to the soil parent material. According to known aspects of sheep feeding behavior (Stuth 1991, Schwartz and Ellis 1981, Huston and Pinchack 1991, Hoffman 1989), we expected to find a distinctive response in sheep diet to the different forage types and community patterns offered by the 2 landscapes studied.

The objectives of the study were: (1) to describe seasonal changes in botanical composition of sheep diets, (2) to compare the sheep dietary habits in those 2 typical landscapes of the Magellanic steppe and (3) to interpret the results in relation to vegetation, landscape and environmental factors.

\section{Materials and Methods}

\section{Study Area}

The study was carried out in the central area of the Magellanic steppe, near Río Grande city $\left(53^{\circ} 47 \mathrm{~S}, 67^{\circ} 42^{\prime} \mathrm{W}\right)$. The climate is semiarid to subhumid, with oceanic characteristics (Walter and Box 1983, Koremblit and Forte Lay 1991). Annual rainfall is $350-400 \mathrm{~mm}$. Cold weather and strong winds are common features year-round; snowfalls are common in winter. According to Frederiksen (1988) 2 landscape types prevail in the area: flat to undulated terrain on gravely glacial and fluvio-glacial deposits (Quaternary landscape), and a long footslope landscape of Tertiary mudstones and sandstones, with lakes in flat depressions (Tertiary landscape). Both landscapes are covered by the Festuca 
gracillima Hooker f. tussock steppe. On the Quaternary landscape (QL), soils are coarse-textured, unsaturated and acidic, giving place to acidophilous variants of the steppe, with shrubs and characteristic acidophilous dwarf-shrubs. On the Tertiary landscape (TL), soils are fine-textured, base-rich and neutral in reaction, resulting in more neutrophilous composition of the steppe, specially rich in short grasses and forbs.

The study was carried out in one paddock selected in each landscape. The 2 paddocks were $23 \mathrm{~km}$ apart under the same general climate and similar altitude. Stocking rates, in accordance to historical records for each landscape-type (Cingolani 1992), were 1 and 1.4 ewe/ha for Quaternary and Tertiary landscape, respectively. Description of the paddocks follows.

Quaternary Landscape (QL): The paddock is in "Maria Behety" station, near "Los Patos" lake $\left(53^{\circ} 43^{\prime} \mathrm{S}, 68^{\circ} 1^{\prime} \mathrm{W}\right)$. It is 2,480 ha and 2,500 wethers graze throughout the year. The landscape is mainly flat, covered with the shrubby tussock grassland of Festuca gracillima, with a layer of variable density of the evergreen shrub Chiliotrichum diffusum (Foster f.) 0 . Kuntze. Also in the uplands appear the cushion heathland of Empetrum rubrum Vahl ex Willd. Lowlands are represented by drainage channels covered with meadows and marshes.

Tertiary Landscape (TL): This paddock is in "Flamencos" station, to the West of "de la Suerte" lake $\left(53^{\circ} 39^{\prime} \mathrm{S}, 68^{\circ} 15^{\prime} \mathrm{W}\right)$. It is 3,236 ha with a stock of 4,500 ewes in a continuous grazing system. Landscape is undulated to hilly, with 2 main communities in the upland sites: the tussock grassland dominated by Festuca gracillima, and the Poa grassland, dominated by Poa poecila Phil. The last one is a very short-grass turf, very common in Tertiary landscapes, thought to be a result of heavy historical grazing of the tussock steppe. In stream valleys there are meadows and, in ponds and lakes, saline marshes.

\section{Vegetation Sampling}

Sampling of the 2 paddocks was aimed to estimate community plant composition in order to interpret dietary differences between them. A total of 35 stands were sampled, during the summer season, in the different communities of both paddocks (several stands per community). Species cover was visually estimated with the Braun-Blanquet abundance-cover scale (Van der Maarel 1979). Aerial photographs (scale 1:40000) were used to map the communities; their respective areas, and that of the whole paddock, were measured with a digital planimeter. Total species composition for each paddock was calculated as the sum of the species cover percentages by community (average of stand sites), weighted by the area covered by each community. Plant species were grouped in 6 forage classes: "tussock grass", "fineleaved grasses", "broad-leaved grasses", "sedges \& rushes", "forbs" and "shrubs". Plant nomenclature followed Correa (1971; 1978) for Gramineae and Compositae, and Moore (1983) for other families of vascular plants.

\section{Diet Analysis}

Floristic composition of herbivore diets can be recognized in fecal samples by microscopic analysis of the plant epidermis with their cuticle (Dusi 1949). Although this technique is imprecise due to differential digestion of species (Martin 1955), it is simple and appropriate to determine herbivore dietary habits in extensive grazing conditions (Holechek et al. 1982, 1983)

Microscope slides were prepared of 52 identified reference plants, according to the method of Sparks and Malechek (1968), modified by Latour and Pelliza Sbriller (1981).

For each paddock, fresh fecal samples were collected in summer (January), fall (April), winter (August) and spring (October) of 1988; numbers of samples varied from 3 to 7. Each sample was composed of 5 pellets from each of 5 depositions, which were assumed to correspond to different individuals, giving a total of 15 to 35 animals sampled. Sample sites were distributed throughout the paddock, in different communities and proportional to sheep intensity of use (Anchorena et al. unpublished).

The fecal sample slides were prepared according to Williams (1969). Epidermal fragments were identified up to genus level; the "sedges \& rushes" group could not be however discriminated. Azorella Lam. and Colobanthus Bartl. were considered as a single group for the same reason. In Festuca, it was possible to differentiate between the 2 species present, thus allowing the evaluation of the dominant tussock Festuca gracillima.

Five slides (sub-samples) were analyzed for each sample at $100 \mathrm{X}$ by traversing the slide systematically. On each slide, 20 microscope fields were observed. The presence/absence of each genus or group was tabulated and the percentage from the total recognizable cuticular fragments for each genus or group was calculated (relative percentage frequency).

Differences among seasons and between landscapes of each diet category were tested with the Kruskal-Wallis test (Zar 1984). This non-parametric ANOVA was used due to the non-normal distribution of data.

\section{Synthesis of Data}

Principal Component Analysis (PCA) (Afifi 1984) was performed on all the individual samples to evaluate diet homogeneity among seasons and between landscapes. The basic data matrix had 33 variables (number of identified categories at the microscope). Differences of diets, by season and by landscape, among the groups obtained by PCA were tested by the Multi Response Permutation Procedure (MRPP), a non-parametric Discriminant Analysis (Zimmerman et al. 1985).

Similarity between pairs of seasonal diets for each landscape, and within each season between landscapes, was evaluated using Czekanowsky similarity index (PS)(Feisinger et al. 1981):

$$
\mathrm{PS}=1-0.5 \sum\left[\mathrm{p}_{\mathrm{ij}}-\mathrm{p}_{\mathrm{ik}}\right] \text {, }
$$

where $p_{i}$ are the resource proportion of item $i$ in the diet and $j$ and $\mathrm{k}$ are the seasonal diets compared.

Diversity in the field and in the diets was measured using the reciprocal of Simpson Index (D) (Hill 1973):

$$
\mathrm{D}=1 / \sum \mathrm{a}_{\mathrm{i}}{ }^{2}
$$

where $a_{i}$ is the resource proportion of item $i$ in the field or in the diet. For both indexes, the diet values were averages for seasons or landscapes.

\section{Results}

\section{Paddock's Composition of Community Types and Forage Classes}

Percentage area covered by each community type in each landscape or paddock is presented in Table 1. The tussock grassland, 
which includes shrubby variants and some dense spots of Chiliotrichum scrub, covers half of the area of the Quaternary landscape (QL). In the Tertiary landscape (TL), the tussock grassland has very few shrubs and occupies a third of the landscape, which is dominated by the Poa grassland. This last type is very scarce in QL, covering only camping sites in north-facing slopes. The extremely acidic Empetrum heath is the second upland vegetation in QL, and is absent in TL. Valley meadows are much more abundant in QL, and the reverse applies to the saline marshes, associated to lakes that are characteristic of the Tertiary landscape.

Relative cover of forage classes for each landscape is shown in Table 2. The dominant tussock grass Festuca gracillima repre-

Table 1. Percentage area covered by each community-type in both paddocks representing the 2 types of landscape studied.

\begin{tabular}{|c|c|c|c|c|c|}
\hline & $\begin{array}{l}\text { Tussock } \\
\text { grassland }\end{array}$ & $\begin{array}{l}\text { Poa } \\
\text { grassland }\end{array}$ & Heath & Meadow & $\begin{array}{l}\text { Saline } \\
\text { marsh }\end{array}$ \\
\hline & \multicolumn{5}{|c|}{ (W) } \\
\hline Quatemary & 56 & 1.6 & 17 & 24 & 1.4 \\
\hline Tertiary & 34 & 54 & 0 & 4 & 8 \\
\hline
\end{tabular}

sents about $20 \%$ of vegetation in the 2 landscapes. The "thinleaved grasses" have higher cover in TL, specially Poa, that reaches 3 times more relative cover. "Broad-leaved grasses" and "sedges \& rushes" have similar cover in both landscapes. Forbs proportion is higher in TL, whereas the shrub category (22.5\%) is practically exclusive of QL.

\section{Seasonal Composition of the Diet}

For their ecological or forage relevance, the following taxa were considered independently: Festuca gracillima, Poa spp and Deschampsia spp. The remaining species had a low relative contribution to the diet and they were grouped in their forage classes. The seasonal variation of these categories in the diet, compared with their proportion in the vegetation, is shown in Figures 1 and 2.

Quaternary Landscape: Seasonal variations in the diet were found $(\mathrm{P}<0.05)$ for Poa spp., Festuca gracillima, "broad-leaved grasses" and shrubs. Species of the genus Poa were the most consumed in spring and summer. In summer, contribution of $P o a$ in the diet was around $24 \%$ and decreased to $8 \%$ in winter, when it was exceeded by Festuca gracillima (24\%) and Deschampsia spp. $(21 \%)$. As suggested by comparing field cover with diet per-

Table 2. Relative cover composition ( $\%$ ) of forage classes in the 2 landscapes.

\begin{tabular}{lcc}
\hline & \multicolumn{2}{c}{ Landscape } \\
\cline { 2 - 3 } Forage classes & Quaternary & Tertiary \\
\hline & 21.95 & 21.57 \\
Tussock grass & 8.42 & 23.14 \\
Thin-leaved grasses & 4.34 & 12.38 \\
Poa poecila & 11.18 & 9.48 \\
Broad-leaved grasses & 7.26 & 7.32 \\
Sedges \& Rushes & 28.69 & 38.27 \\
Forbs & 22.49 & 0.22 \\
Shrubs & \\
\hline
\end{tabular}

centage, Deschampsia supported the highest grazing pressure throughout the year. By the same criteria, Poa was strongly selected in spring, summer and fall, as well as the "broad-leaved grasses" (principally Hordeum L., Bromus L. and Agropyron fuegianum (Speg.) F. Kurtz). The last category represented about $20 \%$ of the diet, except in winter. Festuca gracillima increased notably its diet proportion in fall $(16 \%)$ and reached its maximum in winter (24\%). Shrub consumption was relatively high (12.6\%) in winter. Within the forbs $(-11 \%$ in the 4 seasons), Cerastium arvense L. in fall-winter and Azorella/Colobanthus in springsummer were the principal categories consumed. "sedges \& rushes" were consistently consumed yearlong $(\sim 12 \%)$.

Tertiary Landscape: Differences $(\mathrm{P}<0.05)$ in the diet were detected among seasons only in Festuca gracillima and thinleaved grasses (category formed by Festuca magellanica Lam. and Rytidosperma virescens (Desv.)Nicora).

Poa was the most consumed genus in the 4 seasons (among 22 and $28 \%$ ). Deschampsia followed, accounting for $7 \%$ to $13 \%$ of the diet. Both genera and the "broad-leaved grasses" (Hordeum and Agropyron principally) supported the highest grazing pressure. Festuca gracillima was specially consumed in winter (12\%) and in spring $(8 \%)$. The "thin-leaved grasses" were highly selected in fall. Forbs were abundant diet components all year $(\sim 15 \%)$, the most outstanding categories were Cerastium arvense in winter and Azorella/Colobanthus in spring, as in the Quaternary landscape. The "sedges \& rushes" group had also a consistent use in the 4 seasons $(\sim 13 \%)$.

\section{Main Differences Between Landscapes}

The Tertiary landscape (TL) paddock had $13 \%$ more forage than Quaternary landscape (QL) (Figs 1 and 2, "field cover" bar). The annual diet comprised $74 \%$ grasses, $10 \%$ graminoids and $16 \%$ forbs in TL; and $71 \%$ grasses, $12 \%$ graminoids, $11 \%$ forbs and $6 \%$ shrubs in QL. These similarities of diets in terms of life forms for both landscapes overshadows differences found when diet categories and seasonal periods are considered. The results of the Kruskal Wallis test for the diet categories indicate that only in summer relative use of each category was equivalent for the 2 landscapes. In fall $(\mathrm{P}<0.01)$ and winter $(\mathrm{P}<0.05)$, Festuca gracillima was more consumed in QL. Inversely, "thin-leaved grasses" and "sedges \& rushes" had higher proportions in TL diets in fall, as well as Poa in winter and spring $(\mathrm{P}<0.05)$. There is a shift in the relative use of "broad-leaved grasses" in these seasons: higher for $\mathrm{TL}$ in winter and for $\mathrm{QL}$ in spring $(\mathrm{P}<0.05)$.

\section{Global Diet Analysis}

Figure 3 shows the ordination diagram of the diet samples for the first 2 axes of the principal component analysis. The variance accounted by these 2 axes was $39.7 \%$ and the cophenetic correlation coefficient was 0.81 (Rohlf et al. 1982), i.e., distortion was low. Broadly speaking, Axis 1 accounted for landscape differences, whereas Axis 2 separated seasonal effects. Diet samples containing a high proportion of Festuca gracillima and shrubs were grouped on the left of Axis 1. These samples corresponded to winter and fall diets in the Quaternary landscape. Seasonal diets tend to separate themselves along Axis 2 for both landscapes. Spring and summer samples appear on the positive side, whereas fall and winter ones are on the negative side. This end has samples with a greater proportion of Bromus, Vicia L., Adesmia DC., Cerastium arvense and Rytidosperma virescens. Considering the distribution of these genera in the field, Axis 2 


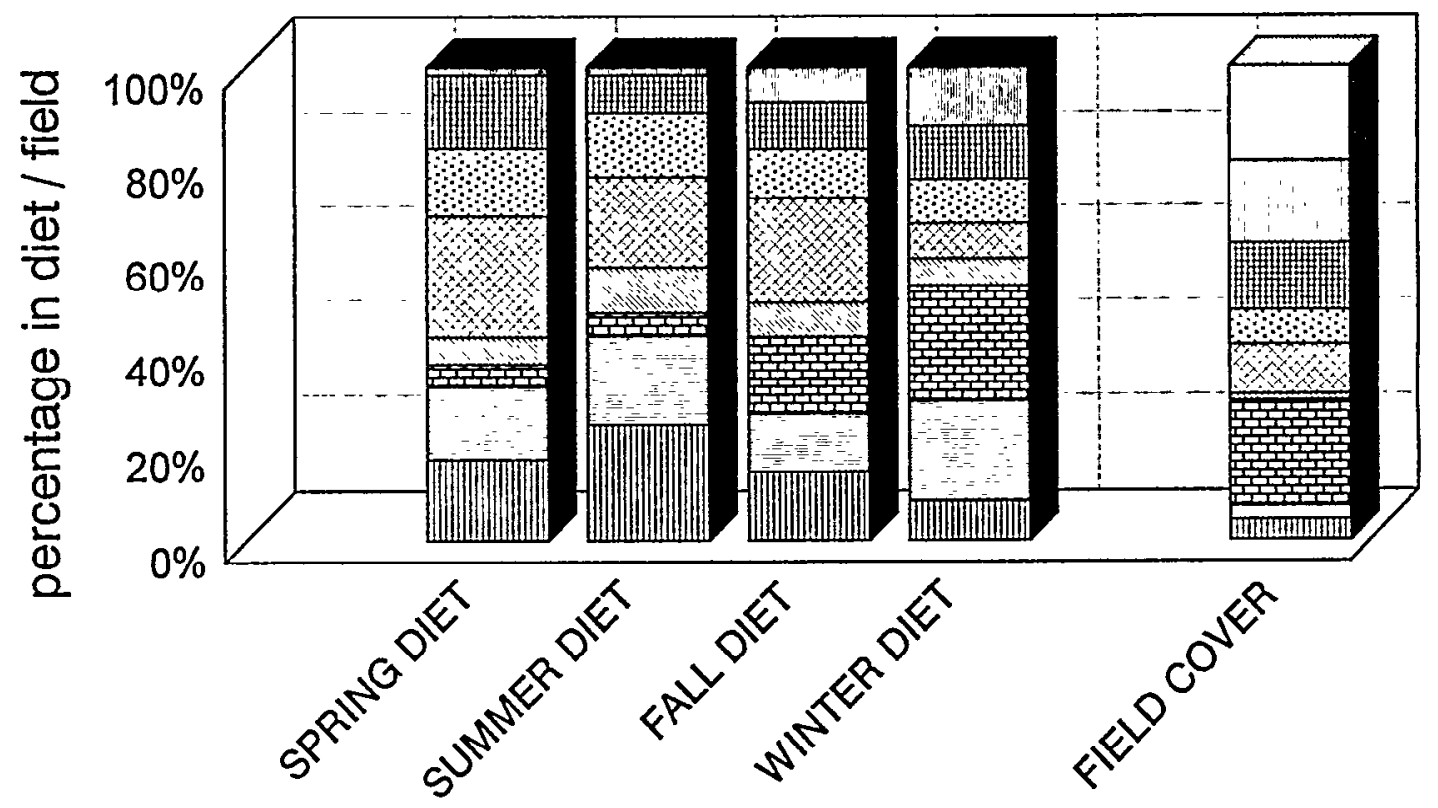

Fig. 1. Seasonal diet and field composition for the Quaternary landscape:

III Poa spp.; Deschampsia spp.; Festuca gracillima; rushes; forbs;

may be interpreted as a slight moisture gradient with the more xerophytic genera in the negative portion. This suggests that in fall and winter animals selected more xeric habitats.

Except for spring and summer diets in Quaternary landscapes, and winter and spring ones in Terrtiary landscapes, significant differences in diet composition were found between all diets compared by the Multi Response Permutation Procedure test. Note that according to this test, taking individually all taxa identified at the microscope, diets from different landscapes were always different.

\section{Diet Similarity and Diversity}

Similarities between pairs of seasonal diets in each landscape are shown in Table $3 a$. Winter and spring diets are the most similar ones (0.80) in Tertiary landscapes (TL), and the most dissimilar (0.54) in Quaternary landscapes (QL). In the QL landscape, similarity values showed greater variation among seasons, suggesting a more variable feeding behavior. If diets of each season are compared between landscapes (Table $3 b$ ) the greater similarity is in summer and the lower in winter. This emphasizes the differential feeding behavior in winter between landscapes, in response to the characteristics of vegetation.

Vegetation of QL is more heterogeneous than vegetation of TL, as it is shown in Table 4 . Considering forage classes, diet diversity is also higher in QL and its greater coefficient of variation indicates that animals shift among forage types along the year.

\section{Discussion}

The results show the relevance of grasses, particularly the genera $P o a$ and Deschampsia, in sheep diets in the Magellanic region. Preference for Poa spp. was reported for other ungulates in southern oceanic climates; e.g. the guanaco (Lama guanicoe) in Tierra del Fuego (Raedecke 1980, Bonino and Pelliza Sbriller 1991) and the reindeer (Rangifer tarandus) in the South Georgia Islands (Leader-Williams et al. 1981). In other regions of Patagonia, under a more arid and continental climate, Poa spp. were also found as the principal component of sheep diet but, unlike Tierra del Fuego, shrubs made a high contribution in summer (Bonvisutto et al. 1983, Bonino et al. 1986). In boreal oceanic regions, sheep consume preferentially grasses, particularly Festuca spp. and Deschampsia spp. (Bullock 1985, Grant et al. 1985).

In both areas studied, sheep increased substantially the intake of the dominant tussock-grass Festuca gracillima during the winter season. Consumption of this fibrous type of forage is generally associated with seasons of scarcity of resources. Bishop et al. (1975) and Squires (1982) report that sheep showed positive pref-

Table 3. Similarity indexes (a) between seasonal diets for each landscape and (b) between landscapes for seasonal diets.

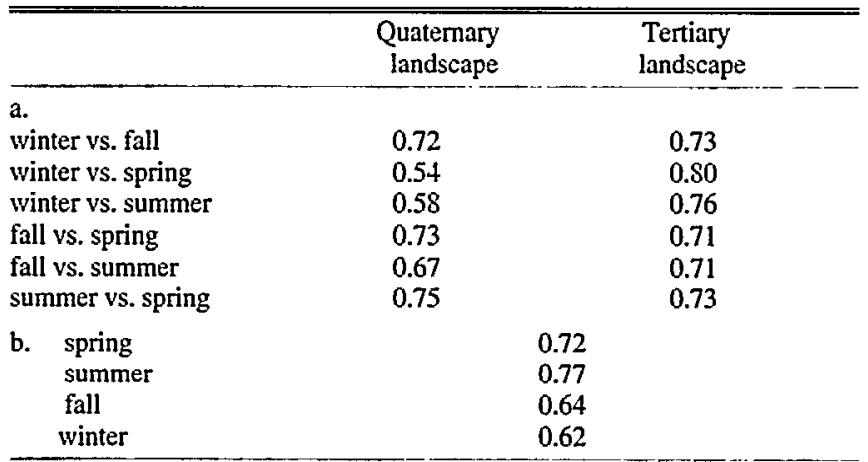




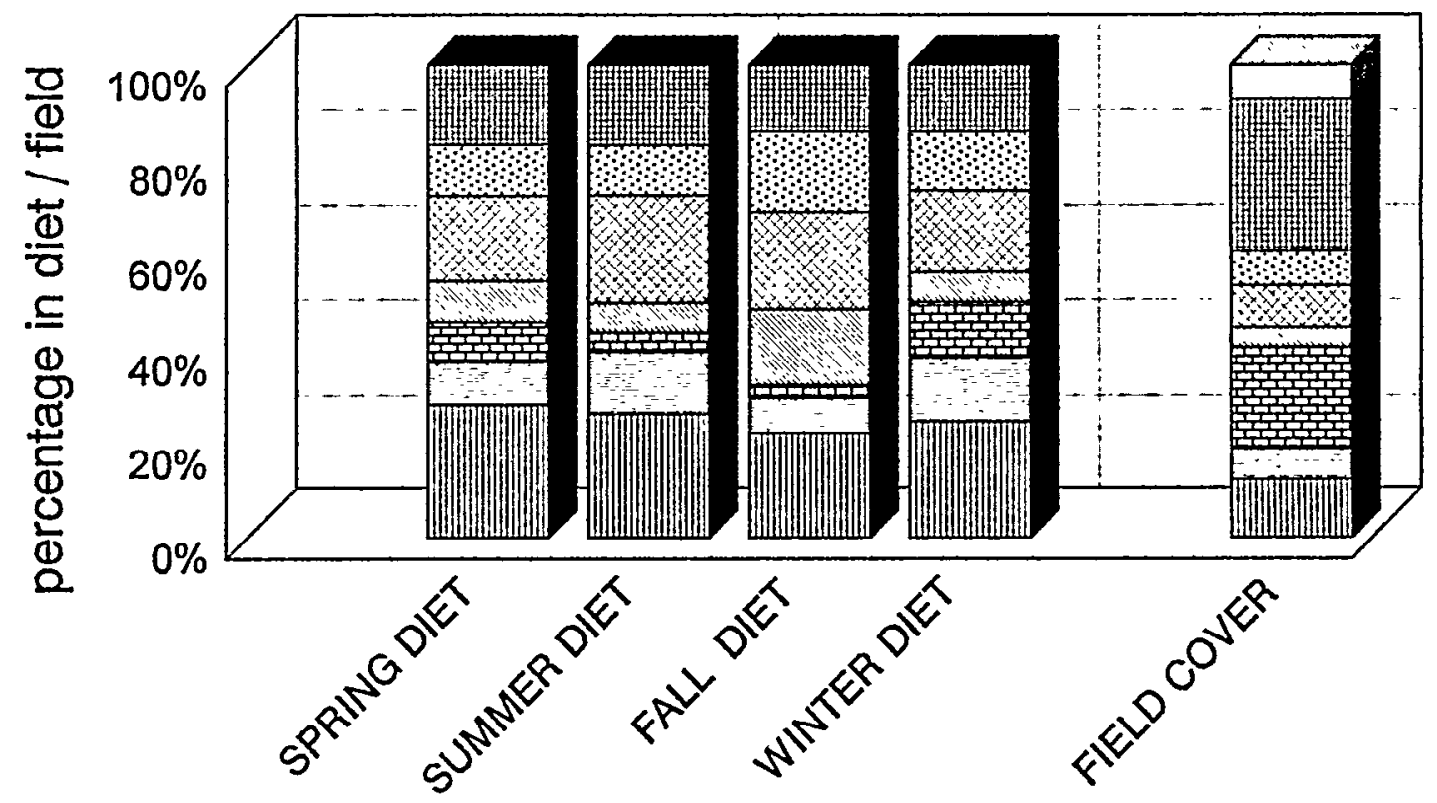

Fig. 2: Seasonal diet and field composition for the Tertiary landscape:

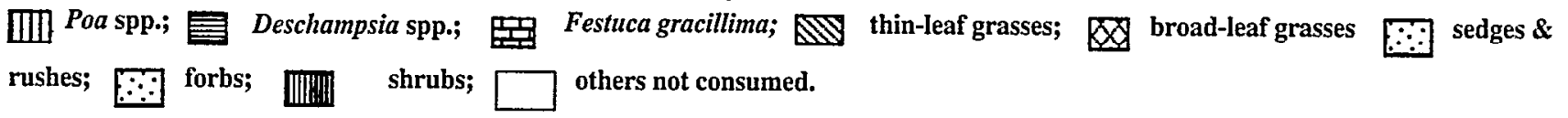

erence for Stipa L. tussocks only in winter. Avoidance of tussocks during the growing season was also reported by Grant et al. (1985) for the tussock grassland of Nardus stricta, an oceanic vegetation type comparable with the Magellanic steppe. Forage accessibility would be playing a key role in our case, since the lower layer of grasses and forbs between Festuca tussocks is frequently covered by snow or ice during the winter season. Higher selection of tussock grasses in snow-covered landscapes has been reported for reindeer (Rangifer tarantus) in the South Georgia Islands (Leader-Williams et al. 1981) and for California bighorn sheep (Ovis canadiensis californiana) in British Columbia (Wikeem and Pitt 1992).

It is interesting to point out that although sheep behave generally as bulk grazers, they consume, when offered, a considerable proportion of shrubs in fall and winter (Fig. 1). The skewed pattern of use of the evergreen shrubs is indicating a forage usually rejected, and probably only utilized as a "quality component" (Huston and Pinchak 1991), in a time of the year when grasses would be less available or less nutritive. In a comparable high latitude oceanic climate, in Scotland, sheep displayed a similar feeding behavior; i.e., they consumed a high proportion of shrubs only in winter (Bullock 1985).

Differences in forage categories in the diets of each paddock suggest that landscape and community heterogeneity has imposed 2 foraging strategies, specially for the unfavorable season. As Table 2 shows, the Tertiary landscape (TL) paddock has a higher contribution of forage classes that form the "stable component" of diets (Huston and Pinchack 1991), specially thin-leaved grasses and forbs. These 2 categories are more heavily consumed in TL throughout the year, including the preferred Poa (Figs. 1 and 2). In the unfavorable season, upland vegetation attains special importance, since lowland communities (meadows and marshes) have very little use (Anchorena et al. unpublished). Thus, the significant higher amounts of Poa and graminoids in TL's diets and, conversely, of Festuca in Quaternary landscapes (QL), for fall and winter (Figs. 1 and 2), reflect vegetation differences between landscapes. It might be likely that in QL, the lower cover of those preferred categories had imposed time-energy constraints in the search for forage (Hanley 1980), leading shcep to depend on the easily reached, low quality Festuca gracillima, even in snow-free periods. Considering gastrointestinal limitations of small ruminants (Demment and Van Soest 1985), sustained consumption of this fibrous forage would require a proteinrich supplementary food. In winter this requirement could only be reached by consuming shrubs, a type of forage that usually maintain a much higher protein content during this season (Cook 1972).

Those main differences in diet selection, together with many others of a more subtle nature, determine a unique composition for each landscape diet, whatever the season considered, as indicated by Principal Component Analysis (PCA) (Fig. 3). As was reported in other studies (Arnold and Dudzinski 1978), differences in sex and physiological function of the flocks were not expected to influence foraging behavior.

Table 4. Diversity of vegetation (by species) and of annual diet (by genera and by forage classes) for both landscapes. Forage types considered were: tussock grass, nther grasses, forbs, sedges $\&$ rushes and shrubs.

\begin{tabular}{lcccc}
\hline \hline & & \multicolumn{2}{c}{ Diversity } & \\
\hline & vegetation & & annual diet \\
\cline { 2 - 5 } Landscape & & by genera & by forage types(CV\%) \\
\hline quaternary & 11.68 & 9.22 & 2.94 & $(19.38 \%)$ \\
tertiary & 10.05 & 7.99 & 2.08 & $(3.89 \%)$ \\
\hline
\end{tabular}




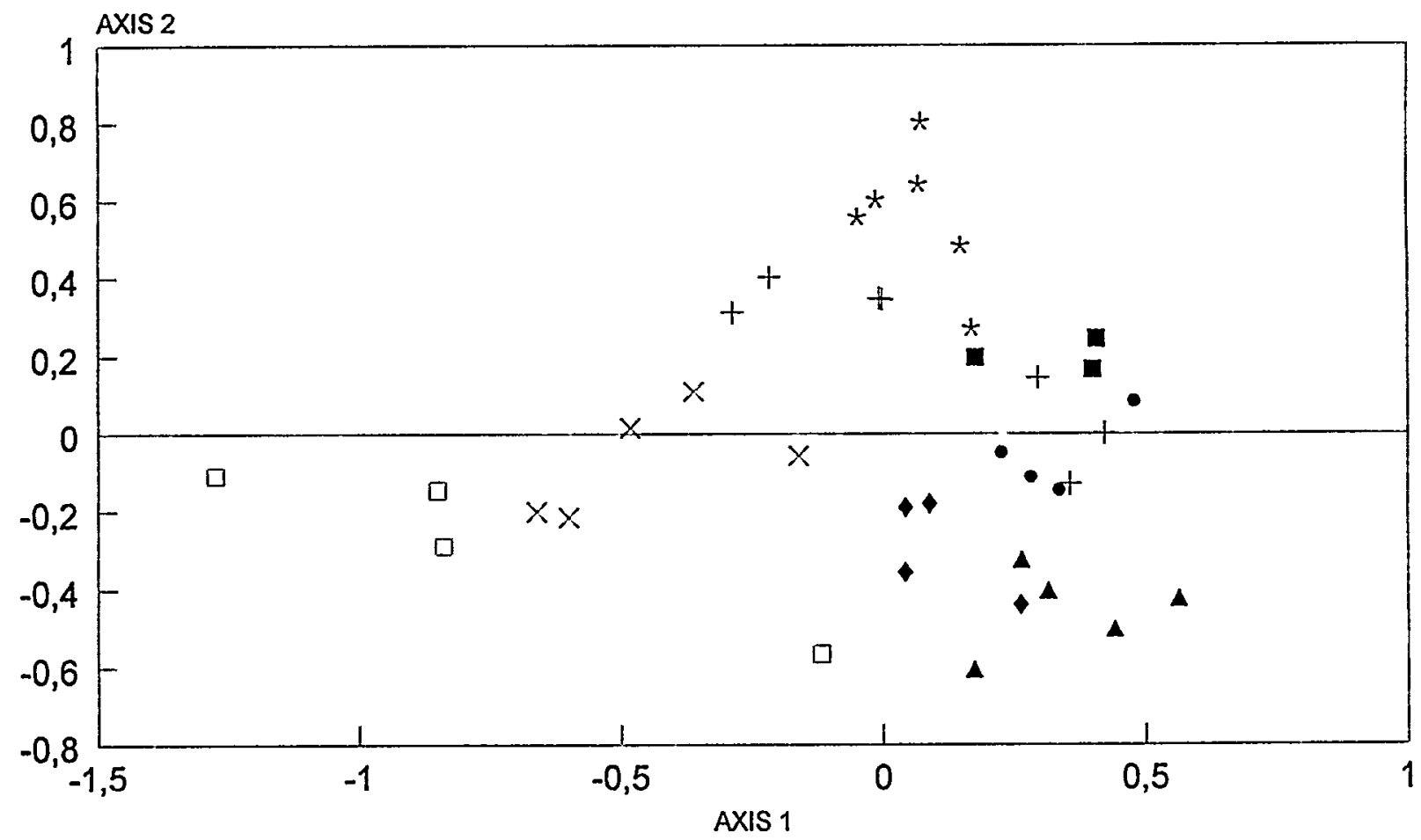

Fig. 3. Principal Component Analysis (PCA) ordination diagram for all diet samples in the 2 landscapes and 4 seasons.

Tertiary landscape:

- spring ; 1 summer; $\Delta$ autumn; $\bullet$ winter

Quaternary landscape:

+ spring; * summer; $\times$ autumn; $\square$ winter

The pattern of diet diversity makes an important difference in sheep behavior for each landscape. It is clear from the distribution pattern of samples in the PCA diagram (Fig. 3), that diets in Quaternary landscapes (QL) are more diverse than in Tertiary landscapes (TL). This is also shown by diet similarity indexes along the year, which are higher and more uniform in TL (Table 3a). Also in terms of forage types, diets are more variable for $\mathrm{QL}$ (Table 4). This emphasizes the ability of sheep to adapt to spatial and temporal changes in forage availability, probably due to their particular morphological and physiological adaptations to maximize nutritional intake (Hanley 1980).

A striking difference in behavior is indicated by the high diet similarity index between winter and spring in TL (Table 3a). This suggests a delayed outcome of the growing season in this landscape, probably due to the fact that the finer soils of TL remain frozen for a longer period. Conversely, spring diet in QL is already reflecting summer foraging behavior.

Landscapes on Tertiary rocks have higher proportion of forage in total vegetation, and higher cover of the main forage-types of the diet. Nevertheless, landscapes on Quaternary deposits have physical advantages in cold and long winters. They have higher abundance of shrubs and tussock-grasses, forage types not affected by the ice sheet or by the snow, that frequently cover the range in that season. The shrub layer is also a good protection of edible forbs and grasses against snow. Especially risky for sheep survival would be those fields of TL, covered by the Poa grassland, with scarce tussocks.

\section{Literature Cited}

Afifi, A.A. 1984. Computer-aided multivariate analysis. Lifetime Learning Publications Belmont, Calif.

Arnold, G.W. and M.L. Dudzinski. 1978. Ethology of free-ranging domestic animals. Elsevier Scientific Publishing Company, Amsterdam.

Bishop, J.P., J.A. Froseth, H.N. Verettoni, and C.H. Noller. 1975. Diet and performance of sheep on rangeland in semiarid Argentina. J. Range Manage. 28:52-55.

Bonino, N. and A. Pelliza Sbriller. 1991. Composición botánica de la dieta del guanaco (Lama guanicoe) en dos ambientes contrastantes de Tierra del Fuego, Argentina. Ecol. Austral 1:97-102.

Bonino, N., G. Bonvissutto, A. Pelliza Sbriller, and R. Somlo. 1986. Hábitos alimentarios de los herbívoros en la zona central del área ecológica Sierras y Mesetas Occidentales de Patagonia. Rev. Arg. Prod. Anim. 6:275-287.

Bonvissutto, G., E. Moricz de Tecso, O. Astibia, and J. Anchorena. 1983. Resultados preliminares sobre los hábitos dietarios de ovinos en un pastizal semidesértico de Patagonia. IDIA 36:246-253.

Bullock, D.J. 1985. Annuals diets of hill sheeps and feral goats in southern Scotland. J. of Appl. Ecol. 22:423-433.

Cingolani, A. 1992. La producción ovina en Tierra del Fuego. Incidencia de los factores ecológicos. Seminario de Licenciatura, Departamento de Ciencias Biológicas. Facultad de Ciencias Exactas y Naturales (UBA).

Collantes, M.B., J. Anchorena, and G. Koremblit. 1989. A soil nutrient gradient in Magellanic Empetrum heathlands. Vegetatio 80:183-193. 
Cook, W. 1972. Comparative nutritive values of forbs, grasses and shrubs. p. 303-310. In: C. M. McKell, J.P. Blaisdell and J.R. Goodin (eds), Wildland shrubs-their biology and utilization. USDA. Tech. Rep. INT-1.

Correa, M.N. 1971. Flora Patagónica. Parte VII: Compositae. Col.Científica del INTA. Buenos Aires.

Correa, M.N. 1978. Flora Patagónica. Parte III: Graminae. Col. Científica del INTA. Buenos Aires.

Demment, M.W. and P.J. Van Soest. 1985. A nutritional explanation for body-size patterns of ruminant and non-ruminant herbivores. Amer. Nat. 125:641-672.

Dusi, J.L. 1949. Methods for the determination of food habits by plants microtechniques and histology and their application to cottontail rabbit food habits. J. Wildl. Manage. 13:295-298.

Feisinger, P., E.E. Spears, and R.W. Poole. 1981. A simple measure of niche breadth. Ecol. 62:27-32.

Frederiksen, P. 1988. Soils of Tierra del Fuego. A satellite-based land survey approach. Folia Geographica Danica XVIIl. Kobenhavn C. A. Reitzels Forlang Rosendahls Bogtrykkeri. Esbjerg.

Grant, S.A., D.E. Suckling, H.K. Smith, L. Torwell, T.D.A. Forbes and J. Hodgson. 1985. Comparative studics of dict selection by sheep and cattle: the hill grasslands. J. Ecol. 73:987-1004.

Hanley, T.A. 1980. The nutritional basis for food selection by ungulates. J. Range Manage. 35:146-15I.

Hill, M.O. 1973. Diversity and evenness: a unifying notation and its consequences. Ecol. 54:427-432.

Hofmann, R.R. 1989. Evolutionary steps of ecophysiological adaptation and diversification of ruminants: a comparative view of their digestive system. Oecologia 78:443-457.

Holechek, J.L., M. Vavra, and R.D. Pieper. 1983. Botanical composition determination of range herbivore diets: a review. J. Range Manage. 35:309-315.

Holechek, J.L., M. Vavra, J. Skovlin, and W.C. Krueger. 1982. Cattle diets in the blue mountains of Oregon, I. Grasslands. J. Range Manage. 35:109-112.

Huston. J.E. and W.E. Pinchak. 1991. Range Animal Nutrition, p. 27-61. In: R. K. Heitschmidt and J. W. Stuth (eds), Grazing management. An ecological perspective. Timber Press, Ore.

Koremblit, G. and J.A. Forte Lay. 1991. Contribución al estudio agroclimático del norte de Tierra del Fuego (Argentina). Ans. Ins. Pat. Ser. Cs. Nats. 20:125-134

Latour, M.C. and A. Pelliza Sbriller. 1981. Clave para la determinación de la dieta de herbívoros en el noroeste de la Patagonia. RIA XVI:109-157.

Leader-Williams, N., T.A. Scott, and R.M Pratt. 1981. Forage selection by introduced reindeer on South Georgia, and its consequences for the flora. J. Appl. Ecol. 18:83-106.

Martin, D.J. 1955. Features on plant cuticule. An aid to the analysis of the natural diet of grazing animals, with special reference to Scottish hill sheep. Trans. Bot. Soc. Edin., XXXVI, pt.IV.

Moore, D.M. 1983. Flora of Tierra del Fuego. Anthony Nelson, England. Missouri Botanical Garden, USA.

Raedeke, K.J. 1980. Food habits of the guanaco (Lama guanicoe) of Tierra del Fuego, Chile. Turrialba 30:177-181.

Rohlf, F.J., J. Kispangh, and D. Kirk. 1982. NT-SYS Numerical Taxonomy system of multivariate statiscal programs. State University of New York, Stony Brook.

Schwartz, Ch.C. and J.E. Ellis. 1981. Feeding ecology and niche separation in some native and domestic ungulates on the shortgrass prairie. J. Appl. Ecol. 18:343-353.

Stuth, J.W. 1991. Foraging behavior, p. 65-83. In: R. K. Heitschmidt and J. W. Stuth (eds), Grazing management. An ecological perspective. Timber Press, Ore.

Squires V.R. 1982. Dietary overlap between sheep, cattle and goats when grazing in common. J. Range Manage. 35:116-119.

Sparks, D.R. and J. Malechek. 1968. Estimating percentage dry weight in diet using a microscopic technique. J. of Range Manage. 21:264-265.

Van der Maarel, E. 1979. Transformation of cover-abundance values in phytosociology and its effects on community similarity. Vegetatio 39:97-114.
Walter, H. and E.O. Box. 1983. Climate of Patagonia, p.432-435. In: N. E. West (ed), Temperate Deserts and Semi-deserts. Elsevier Scientific Publishing Company, Amsterdam.

Wikeen, B.M. and M.D. Pitt. 1992. Diet of California Bighorn sheep, Ovis canadiensis californiana, in British Columbia: assessing optimal foraging habitat. Can. Field Natur. 106:327-335.

Williams, O.B. 1969. An improvement technique for identification of plant fragments in herbivore faeces. J. Range Manage. 22:51-52.

Zar, J.H. 1984. Biostatiscal analysis. p. 176-79. Prentice-Hall, Inc. N.J. Zimmerman, G.M., H. Goetz, and P.W. Jr. Melke. 1985. Use of an improved statiscal method for group comparisons to study effects of prairie fire. Ecol. 66:600-611. 